\title{
Student with special needs and mathematics learning: A case study of an autistic student
}

\author{
Sabaruddin Sabaruddin ${ }^{1 *}$, Rosnidar Mansor ${ }^{2}$, Irfan Rusmar ${ }^{3}$, Fadila Husna ${ }^{1}$ \\ ${ }^{1}$ Department of Mathematics Education, Institut Agama Islam Negeri Langsa, Indonesia \\ ${ }^{2}$ Department of Educational Studies, Universiti Pendidikan Sultan Idris, Malaysia \\ ${ }^{3}$ Department of Agribusiness Crude Palm Oil, Politeknik Teknologi Kima Industri Medan, Indonesia \\ Corresponding Author: sabaruddin@iainlangsa.ac.id
}

ARTICLE INFO

Article history:

Received: 17 June 2020

Revised: 21 August 2020

Accepted: 23 August 2020

Published online: 30 August

2020

Published regularly: October

2020

\section{Keywords:}

Autistic students, teacher

behavior, mathematics

learning

\section{ABSTRACT}

The provision of mathematics for autistic students has not gained a special concern. In fact, many autistic children have good mathematical skills and some are even excellent. It imposes teachers to formulate and create effective strategies to teach autistic students. The purpose of this study was to determine teacher behavior and how to teach students with autism effectively. This study was designed as a qualitative case study research. It involved mathematics teacher, assistant teacher, student, and parents. Data were obtained through observations and interviews. The autistic student's attitude and behaviors during mathematics learning were investigated. It included examinations on the supporting and inhibiting factors in mathematics learning in a school for students with special educational needs/SLB. The result indicated that mathematics learning for students with autism as performed in inclusive education was different from regular education programs, in which teachers were required to adjust materials with students' psychological condition. It also revealed that the students had had focus issues; hence materials were mostly conveyed outside the lesson plan, particularly to introduce the basic material. The supporting factors included parents' motivation for the student to learn and behave appropriately and well-designed learning packages. Meanwhile, limited learning media and school facilities, as well as the absence of special teachers for students with autism, became the inhibiting factors for mathematics learning.

(C) 2020 Universitas Muhammadiyah Surakarta

\section{Introduction}

All human beings are born equal, in which they have equal rights and needs for education (Eskelson, 2019). Essentially, all humans are created equal in dignity, regardless of the gender, physical abilities, health, and other conditions that distinguish them, as well as equality in education (Contreras et al., 2020; Hu et al., 2018). Nevertheless, not all children are born under normal circumstances; some are born with different conditions and special needs (Sabaruddin et al., 2019). Those kinds of students will require special treatment in all aspects compared to other children who do not have special needs. Ilona 
(2019) found that the birth rate of children with special needs increased not only in Indonesia but also worldwide. Moreover, Onaolapo (2017) also stated that most of children with special needs are autistic children. According to Budiyanto (2020), approximately 1 in 150 children is autistic. Riany, Cuskelly, and Meredith (2016) revealed the Ministry of Health data in which approximately $1.14 \%$ of 237.5 million people in Indonesia are linked to autism cases. In general, children diagnosed with autism are characterized by difficulties in social communication and interaction, communication with the environment, behavior, and academic achievements, as compared to children at their age (Istiarsyah et al., 2019). In addition, Luckevich (in Hansen, 2014) stated that autistic students are slower in integrating information. Therefore, according to Hansen (2014), methods for delivering knowledge without disrupting the basic needs are required in the process of teaching students with special needs.

Mathematics is the foundation of science in everyday life (Yu-Han $\mathrm{Hu} \&$ Jun Xing, 2018). Mathematics is not an exclusive subject solely intended for intelligent students, but it is an experience that must be possessed by every child, including those with autism (Gevarter et al., 2016). However, mathematics has a challenge. The report of the PISA test in 2015 divulged that the mathematical skills of Indonesian students were classified low. It urges the struggle to improve mathematics learning. In the context of mathematics for autistic students, teachers need to facilitate and support students in optimally learning mathematics (Holm et al., $\underline{2020)}$.

The poor mathematical skills of Indonesian students shall motivate both teachers and students to enhance their skills. In the context of mathematics learning for students with special needs, teachers must provide the best support to optimize autistic students' skills in learning mathematics. Nevertheless, the materials must be tailored specifically and appropriately for students with diverse special needs (Ngiamsunthorn, 2020). It is very influential in every stage of student learning development. The development of students with autism, in fact, is distinguished in terms of behavior, social communication, and social interaction between students, depending on the level of the obstacles (Burns, 2012).

However, the principles and levels of learning in Indonesian schools for students with special needs (Sekolah Luar Biasa/SLB) are not significantly different from those of regular schools. They also provide education services according to the national curriculum, including mathematics (Sugiman, Suyitno, Junaedi, 2020). In fact, mathematics is related to daily life, i.e., patterns, structures, and logical and systematical principles formulated in equations or theorems (Faragher et al., 2017). It is a compulsory subject at every level of education, including schools for students with special needs. It has been arranged in the school curriculum that the relatively large portion of mathematics is exhausting for students. Consequently, it should be devised as attractive and realistic as possible based on the needs of students. Teachers need time and a gradual process to introduce mathematics to students.

Therefore, SLB teachers should provide some slightly different methods to increase the students' willingness and motivation to learn mathematics (Tolentino, 2016). One of the factors that affect students' mathematics learning outcomes with special needs is the teacher's role and teaching method, which is significant to improve student achievement in mathematics learning (Xin \& Tzur, 2016). Students with special needs have different characteristics from those of traditional schools in which they require special assistance in learning mathematics (Rodd, 2006). Learning-teaching plans in SLB include activities to convey materials to students with special needs; hence they will have adequate skills and 
knowledge for their development (Sabaruddin et al., 2019). It entails conventional classes with teachers and students, while mathematics learning also requires learning media, typical methods, and constructive and supportive circumstances (Powell et al., 2020). Additionally, teachers are required to innovate actively and be creative in performing research and development of teaching materials to facilitate learning activities, especially in mathematics (Tzanakaki et al., 2014).

Similarly, teacher's attitude, behavior, and personality, "the level of knowledge possessed by the teacher and how teacher conveys materials to students also determine student learning outcomes" (Sukardjo, 2020). Teachers in "special" schools certainly face specific barriers in conveying materials to students than those in regular schools (Santos et al., 2017).

According to Sabaruddin (2019), student achievement in mathematics learning must be supported by sufficient facilities and infrastructure, i.e., learning media and props, tailored to the needs of students in SLB. Meanwhile, students with autism also have their own characteristics that should be taken into account while devising learning plans, i.e., physical, mental, emotional, and social conditions (Rexroat-Frazier \& Chamberlin, 2019). It is suggested that they are provided by special learning programs, particularly in mathematics, which involves strategies, methods, or approaches as well as the type of education that accommodate educational services for different, special needs of students (Ngiamsunthorn, 2020).

Mathematics learning will improve students' analytical skills and support character building (Kim et al., 2019). Many studies have linked students' mathematics and character building, both implicitly and explicitly (Santos et al., 2017; Suhuddinul \& Suparman, 2019). In this context, it is expected that students with special needs are able to improve their personalities and social interaction skills (Kroesbergen \& Johannes, 2003). Learning mathematics raises awareness of the importance and various applications of mathematics in students' daily life (Moscardini, 2015; Palinussa, 2013; Tolentino, 2016).

Consequently, teachers are required to be creative in developing strategies or methods to provide the best education for students with autism (Arthur et al., 2017). The educational environment for students with autism is more complicated than that for regular students; thus, learning strategies and approaches must be selected based on their special needs (Mensah \& Badu-Shayar, 2016). A key to inclusive education is "fun learning" designed to attract students with special needs. In terms of psychological state, their learning abilities and attentiveness are lower than regular students.

Therefore, it is necessary to conduct a scientific study on implementing effective mathematics learning for autistic students in Langsa. The result of the study is expected to provide input for the implementation of mathematics learning. Furthermore, it can provide some recommendations in effectively conveying mathematics subjects for students with special needs, including autistic students. Therefore, this study focuses on students with special needs in learning mathematics. The aims are to observe teachers' attitudes and behaviors during the learning activities, assess students' responses during mathematics learning, and eventually formulate an effective method for conveying mathematics to students with special needs.

\section{Research Methods}

The present study is a qualitative case study research (Creswell, 2007). The research subject was determined based on the topic of discussion, namely mathematics learning for 
students with autism in a school for students with special needs/SLB. As the research subject, an 8th-grade student with autism of the 2019/2020 academic year in an SLB in Langsa City, Aceh, Indonesia, was involved. SLB Kota Langsa has many special needs students, including children with autism, but for children with autism, it is unique in the learning process. Autistic students who were the subject of this study were diagnosed with autistic disorder, characterized by a lot of activity with objects and easy to analyze. Autistic students in SLB Kota Langsa like objects related to mathematics and calm during math lessons even though they have to be with the teacher of their choice. Teachers involved in this study have a special education undergraduate qualification, with 11 years of teaching experience at SDLB Kota Langsa, and have received educator certification.

Data were obtained from direct observations in the classroom one month for five meetings with different math learning topics, particularly on the research subject. It was arranged meticulously from the initial process of the classroom to the dismissal of the classroom. The data were recorded in the forms of notes and videos and processed into the anecdotal record. From the observations, information on students' participation with autism in the class, learning strategies and approaches used by teachers, and learning media and resources for mathematics learning were obtained. The factual, thorough, and detailed conditions in the classroom were described.

In addition to the observation, in-depth interviews with the mathematics teacher, assistant teacher, and school principal were carried out. The interview was also done with the parents of the research subject. They had previously given their consent and agreed to contribute to this study. The data analysis in qualitative research was carried out interactively and continuously to reach a saturation level. It was indicated by the absence of new data or information. Activities in the analysis included data reduction, data display, and conclusion drawing or verification. For the validity of the data obtained, this study made adjustments to the interview data with the teacher and parents, so it adjusted the observational data.

\section{Results and Discussion}

\section{Learning Process}

Learning media and props included whiteboard, eraser, and protractor. Large wooden protractors' unavailability became a shortcoming in conveying the material, but it was overcome by giving individual explanations to students. Consequently, it required a long time to present the material. However, every student practiced how to use the protractor with the teacher's guide. At the same time, since there were only two protractors, the students used them interchangeably in which they learned how to share with peers. The allocation of time is not necessary for the learning process of students with autism. The teacher explained that students with autism should not be forced to complete any tasks in this context; the lesson plan. Otherwise, they would have tantrums or other aggressive behaviors. Hence, the lesson plan mainly serves as a non-binding reference. In the interview, the teacher explained:

"Lesson plan or RPP is not necessarily a benchmark. The most important is that students understand the objectives of learning. When they are not an enthusiast in learning, we should not force them. Otherwise, they will have a tantrum or be aggressive. In such a case, we will persuade them, but if it does not work, we let it be."

Similarly, the parents of students with autism also revealed the case. In the interview, they claimed: 
"Our child will have a tantrum for not allowed to have or do something. As we are tough, our child will scream and break things, and occasionally hit things."

Teaching material is information that will be conveyed to students through the learning process. During the observation, the material discussed was the angle, i.e., measuring the angle's magnitude on a plane using a protractor. The teacher carefully explained how to measure the angle on the flat plane and start editing by explaining how to place the angle's base on a flat plane to each student. Giving a personal approach indicates that the teacher has mastered the class and provided full attention. There is no explanation of the relationship between the lesson and knowledge related to real life. Mathematics learning is perceived as an abstract one. The concrete explanation is recommended; hence students will acquire the concepts and use them in real life. The process of learning mathematics for students with autism can be initiated by introducing patterns and attributes, i.e., using pictures or concrete objects around them (Burns, 2012).

According to Santos (2017), children with autism experience challenges that affect the ability in sensory processing, remembering, language function, and attention. It also occurs in the limbic system as the center of emotions so that they have difficulty in controlling emotions, easily having tantrums, and being temperamental and aggressive. Consequently, in the learning process, they are allowed to have their own pace without expecting learning outcomes.

The observation also revealed that the student was given the opportunity to pose questions or give opinions. The students questioned the shape of the trapezoid drawn by the teacher on the whiteboard. The teacher described it plainly and specifically. It shows that students can express ideas or opinions shale; the teacher responds positively to them. This question and answer activity create an interactive and responsive situation. Moreover, the teacher would be more involved in interaction with active students (Santos et al., 2017). It can be argued that the question and answer is a strategy to keep the class active.

Learning activities are communication processes to convey messages from educators to learners with the aim the messages are received appropriately; hence they can affect the understanding and promote behavioral changes. Communication is significant in the process of mathematics learning activities. According to the observation, the teacher explained a material to the students using a clear, fluent, and simple language. The written explanation was sufficient and correct. It was indicated when the teacher explicated the center and baseline of the protractor and flat shapes' vertex. Lanani (2013) argued that effective communication skills are necessary for mathematics. Both teachers and students are expected to communicate their ideas in verbal and written forms, coherently and clearly, as well as use mathematical language to express their ideas appropriately, manage their ideas through communication, analyze and evaluate their ideas. The observation revealed that the teacher explained the material using simple language to students with autism and clear sign language to students with hearing impairment. In the interview, the teacher informed the communication method for the class:

"For students with hearing impairments, we use effective, proper, and simple sign language. While for students with autism, plain language is sufficient."

In addition to the appropriate language, assignments were also tailored to students' cognitive and developmental stages. Learning activities involved assessment, follow-up activities in the form of assignments, and closing. Based on observations, before the end of the class, the teacher evaluated the assignment's results. It entailed enrichment by posing questions with slightly higher difficulty levels for those who understood and answered the 
questions independently, implying the student could solve problems without assistance. The teacher explained the situation during evaluation activities:

"Assessment is carried out by observing the final evaluation of student performance on the individual basis, active involvement in the class, as well as attitude and behavior."

The teacher explained:

"Certainly, the students are encouraged to summarize the material given to them previously."

One of the strategies to achieve the optimal result in learning is through summary as closing. Nevertheless, it was not performed by the teacher during the observations. Ismail (2011) suggested the importance of summary for students to recall the main ideas of a concept and reduce the difficulties and ambiguity experienced by students. The summary was absent from the observation due to the class's situation where several students had not finished the practice questions. However, the teacher stated that one of the learning activities was to summarize the material that allowed students' participation.

\section{Autistic Students' Attitude and Behavior in Mathematics Learning}

According to parents' information, they recognized the particular attitude and behavior of their child and decided to find out about it immediately. It led to their child's diagnosis of autism. The parents described the case in the interview:

"We realized that our child has special needs since his early years. He is hyperactive. He seems to be uncaring or unconcerned when someone calls him. He has difficulties in speaking. It took five years for him to begin talking. It is common for us to find him breaking any objects in front of him, pouring water into TV or radio, and being lascivious. He is also suddenly running into the street and quietly standing in the middle of it, falling, having tantrums when shopping, and other aggressive behaviors. As soon as we began to realize it, we sought information from magazines and others. From the magazine, we recognize it is called autism, as well as dietary restrictions and how to treat children with autism. Later, we saw a pediatrician, and after he was examined, the doctor also diagnosed him with autism."

Characteristics of autism are shown by infants or toddlers who do not respond when they are called, picked up, or kissed while older children with autism are reluctant to interact with others. They might not be interested in people and rather occupied in their own things without any company (Hallahan, Kauffman, James \& Pullen, 2006). Lipsky (2019) also reaffirmed that children with autism have a propensity to perform repetitive, hyperactive, or active motor movement throughout the day, and are more attracted to objects than humans. According to Graham (2015), autistic children will behave directionally: going back and forth, running, climbing, spinning, jumping, as well as having difficulties in speaking and having frequent tantrums. Hallahan also explained the characteristics of children with autism, i.e., often repeating words that they had just heard or had never heard of. They often talk to themselves or repeat part of words or song excerpts from advertisements on television and say it aloud in front of other people in inappropriate circumstances (Hallahan, D., Kauffman, James M. \& Pullen, 2006). It is following the observation results in which during the learning process, the research object said bad words several times. He suddenly called the teacher "a loser" during the class and "a lazy one" to substitute teachers who could not immediately find a marker. During the observation, he sang when he was weary during the class. The song was a popular one; hence he recalled some parts of the lyrics. The parents of research subjects informed similar habits in which their child would often memorize and repeat words that he heard or watched. 
"He hears and memorizes some bad words from cartoons and movies such as Sponge Bob and war movies."

During the observation, it was noticeable that the research object was distracted. He did not fully concentrate when reciting do'a at the beginning of the class and reciting Surah Yasin at the Praying Room. Unlike other students, he was enthusiastic in neither responding questions from the teacher nor taking a note. He was frequently uneasy and distracted during the class: turned his head to the left and right, rocked his chair, put his head on the table, called out to others, and walked around the class. These attitudes and behavior are forms of the repetitive or stereotyped pattern of behavior. Hallahan suggested that people with autism usually display repetitive or stereotyped behavior and motor movements such as spinning objects, hand flapping, and rocking, similar to visual impairment. Another characteristic is perseverance with certain objects (Hallahan, D., Kauffman, James M. \& Pullen, 2006). One of the learning activities is presented in Figure 1.

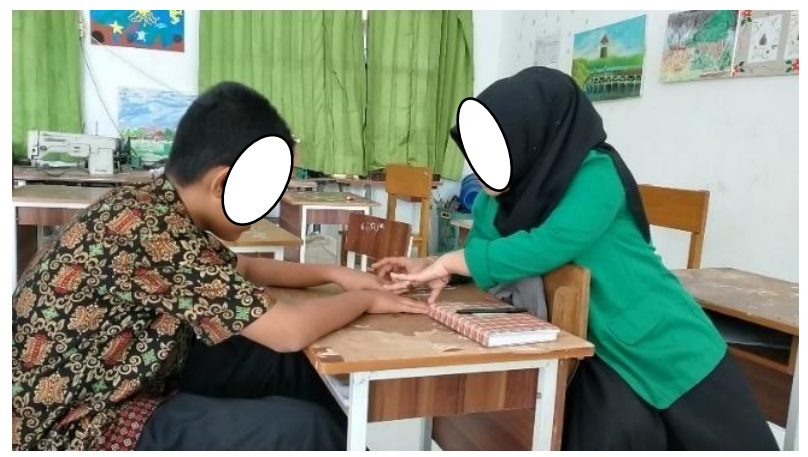

Figure 1. Autistic student activity, with special assistance from the teacher

He also used an irregular structure of language, even seemingly disengaged from the surrounding. His parents informed similar attitude:

"Sometimes, he utters meaningless words. So, we cannot understand what he talks about."

Children with autism are unable to establish passable social interactions, lack of eye contact, poor facial expression, and poorly directed movements (Hallahan, D., Kauffman, James M. \& Pullen, 2006). Hunt et al. (ㅁ16) suggested that students with autism had a propensity to avoid eye contact during social interaction and babble words that others could not seize. It was confirmed by the research object who avoided eye contact during interviews and interaction in the class. He often looked down at the floor when communicated or interacted with others.

\section{Supporting Factors in Mathematics Learning for Student with Autism}

From the observation, the research object occasionally had heavy-eyes and yawned during the class. The teacher explained that he often stayed up late at night. His parents confirmed that his habit of watching movies made him stay up until midnight. It was allegedly the cause for his lethargic during the class as testified by the parents:

"When his favorite movie is played on TV, he stays up until late at night to watch it, yet we accompany him."

During a conversation with the teacher concerning the research object's attitude and behavior, he noticed that he was being discussed and later joined the conversation, insisting that he was not autistic. He was convinced about it during personal interaction. His parents also confirmed the case: 
"No, he does not seem to know that he is special. He even tells us that he wants to go to college."

Mathematics learning in the SLB in Langsa City has its own challenges. The supporting and inhibiting factors in mathematics learning are elaborated in the following section.

\section{Supporting Factors in Mathematics Learning for Students with Autism}

According to the parents' interview, character-building had been initiated as soon as they recognized the symptoms of autism in their child. The result of observation also showed that the research subject could understand mathematical concepts as indicated by his ability to correctly and systematically solve problems. The sample of student's work is presented in Figure 2.
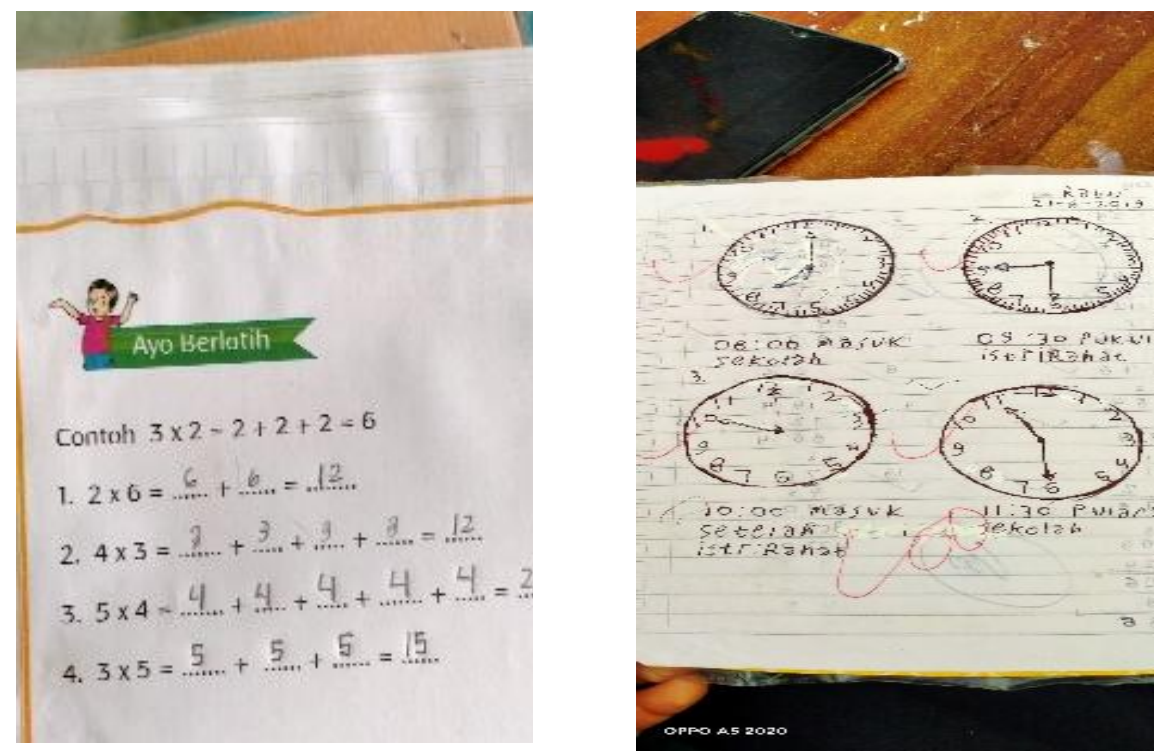

Figure 2. The sample of the student's answer

Based on Figure 2, it can be declared that autistic students' ability to solve problems is relatively lower than children of the same age. In addition, there is a habit of answering questions based on repetition. As the research subject was posed to question dissimilar to the example, he faced difficulties in solving it and preferred to ignore it. Usually, students will easily answer questions related to routine activities such as what time they wake up in the morning, go to school, have a break, and go home. It implies that it will be easier for them to understand mathematical concepts by relating them to daily habits and activities. It is reaffirmed by therapy activities that require students to perform a lot of repetitive actions, such as repeating words, writing numbers, adding up objects, mentioning names of friends, and asking for something.

According to Andersa (2011), the concentration of students with autism can be improved with a variety of techniques. However, such therapies require the participation of all related parties. In addition to special institutions or schools, home therapy is considered to be necessary. The parents revealed that they regularly performed speech therapy, eye contact therapy, and dietary restrictions from the interview. They informed the techniques as follows:

"We learn how to talk to him and instruct him to call his mother, father, brother, or sister. In addition, we learn how to perform eye contact therapy. He will be situated between the wall and a table and invited to 
make eye contact with us. As he starts to have a tantrum, we tell him that he will be hugged. With such a method, he usually prefers to continue the therapy. We have done it for years. Now, if we instruct him to make eye contact when talking, he obeys us although it occasionally has to be a little coercive".

Based on the parents' information, dietary restrictions were done only in the early years of the diagnosis. After the research subject is able to interact with others, diet is no longer a concern. The parents explained it during the interview:

"For dietary restrictions, we cannot manage it anymore. Our child has been able to go to the kiosk and buy anything he wants. Consequently, we cannot control his daily snacks. He is not allowed to consume chocolate and snacks with MSG."

One supporting factor in mathematics learning for students with autism is parents' involvement in guiding and educating their children. Collaboration between parents, teachers, and schools in examining student development is also significant (Bagley et al., 2001; Loughran, 2008). As any irregularities occur, i.e., slow speech and obstacles in social interaction, parents are required to suspect the possibility of autism in their children, that can be intervened by immediate therapy. According to Sukys (2015), the involvement of helpful and active parents in the character-building is a supporting factor in the learning process. It is signified by students' attitudes and behavior that follow and understand instructions and interact with peers and older people.

The teacher also reaffirmed it during the interview:

"We notice that students with hearing impairment are helpful to a peer who has autism. They build good interaction and mutually accept the characteristics of others".

Another supporting factor in mathematics learning for students with autism is a mutual respect that should be appeared in the school community. A constructive school environment leads students with autism to feel comfortable, supporting the process of learning mathematics (Andersa et al., 2011; Hansen, 2014; Joubert \& Slabbert, 2017). Based on the observation, mutual respect and acceptance among the school community members have been instilled appropriately. It creates a comfortable and amusing situation. In such an environment, students with special needs feel acceptable for equal rights in education with regular students (Dorcas, 2011). It was indicated during spiritual coaching where students with assorted special needs were joined in a forum. They seemed to respect, provide assistance, and support each other.

\section{Inhibiting Factors in Mathematics Learning for Students with Autism}

The teacher stated that the research subject was grouped in class for students with hearing impairments. Due to an incident and as a result, he was moved from his initial class to the same grade. Regarding learning materials, they were similar for the autistic students' class. The teacher stated it as follows:

"Currently, I decided to convey the same materials to students with autism and those with hearing impairments since I cannot only focus on one student. My basic education is to educate those with hearing impairments; therefore, my experience in effective learning for students with autism is inadequate."

The interview revealed that the implementation of mathematics learning for students with autism was similar to that of students with hearing impairments. The materials were not modified at all, although the National Education Agency stipulates the requirement to adjust learning materials to students with autism. Modification is essential to relate the materials to the respective abilities of students with special needs. Professional competence and teaching experiences are significant factors in teaching students with 
special needs (Daiva, Alifanovienè, 2011; Muttiah et al., 2018). Another inhibiting factor in mathematics learning for students with special needs is the teacher's educational background. Basically, teachers are divided into special/non-regular and regular teachers; the educational background is related to their latest major in education (Akmanoğlu \& Ersan, 2020). It is distinguished into special teachers who have experiences coping with students with special needs and regular teachers who have no such experiences. The lack of professionalism was indicated by the absence of the Lesson Plan (RPP) that should be prepared before learning activities and a specific list of activities; hence materials were determined situationally. In addition, the teacher gave similar material to students with autism and those with hearing impairments. It indicates the difference between special and regular teachers, particularly related to the level of experience in teaching children with special needs.

From the teacher's information for autistic students, the research object was moved to class for students with hearing impairments since he felt uncomfortable and did not cope well with the class. The teacher explicated that students with autism are inclined to have tantrums under such a situation. Nevertheless, the research subject is convenient in learning with teachers who have taught him for a long time or understand his characteristics. The teacher for autistic students gave the information as follows:

"He will be glad to study with teachers whom he likes and is comfortable with. He frequently expresses it by hugging and giving compliments to his favorite teachers. On the contrary, he behaves strangely to irritate teachers he dislikes by propelling bad words, being aggressive, and even hitting them."

During the conversation with the teacher for autistic students, the research subject came to the classroom and seemed to seek attention. He questioned unimportant matters and, at the same time, hugged and helped the teacher evaluate his maths exercise book. This teacher is one of his favorite teachers as she has been his mentor since the first year of his elementary school.

According to Alnahdi (2019), the interaction between teachers and students with special needs is in line with the learning program's implementation. Moreover, Sabaruddin (2019a) argued that the teacher reaffirmed it by arguing that students who have attention problems will certainly experience a lack of concentration in any situation. They are very reactive to external stimuli; hence it is easier for them to be distracted during the learning process. At each step of mathematics learning, high concentration is required; hence any attention problems are a barrier in improving mathematical skills. Briefly, students with autism feel uneasy and uncomfortable interacting with particular teachers or new people, especially with teachers who do not pay more attention. The experience of direct interaction between teachers and students with autism is important to support the learning process.

Another inhibiting factor is the lack of acceptance of the surrounding environment (Banda \& Kubina Jr., 2009). As a result, children with autism perceive that they are alienated and different from others. Student's social environment often hampers mathematics learning, i.e., family, school, and community. The non-supportive social environment becomes an inhibiting factor for a student's performance in mathematics learning (Hansen, 2014; Mensah \& Badu-Shayar, 2016). Unfavorable attitudes and behaviors of the community, e.g., the lack of tolerance and mutual respect toward children with special needs, can cause depression and self-isolation. In this situation, they tend to be discouraged in attending learning activities, inhibiting them to improve their skills. 
According to Graham ( $\underline{2015})$, the inhibiting factors in mathematics learning for students with autism are seen from several aspects: students, teachers, and the social environment (family, school, and community). In the present study, insufficient facilities became an inhibiting factor in mathematics learning. Due to the limited number of classrooms, the school had to merge students of three different grades in one classroom. Subsequently, the lack of availability of learning media (as indicated by the absence by large wooden protractor during observation) also impeded the process of mathematics learning. Meanwhile, Suhuddinul (ㅁ19) claimed that learning media could increase student motivation and creativity in mathematics learning.

\section{Conclusion}

Mathematics learning for students with autism in SLB is significantly different in terms of the delivery processes, comparing to students in regular schools. The teacher of special students must adjust the material in correspondence to the volatile psychological condition of students. This study reveals the attitude and behavior of students with autism in mathematics learning. They have a concentration problem; thus, the materials are not conveyed based on the lesson plan; instead, the teacher introduces the materials' basic concept. The supporting factors include parents' active involvement in providing motivation and assistance both in learning and character-building and optimal learning outcome as the result of a well-designed learning package. Meanwhile, the inhibiting factors include the lack of learning media, insufficient facilities, and special teacher absence for autistic students. Further research needs to be done to develop appropriate mathematics teaching materials for autistic students to support them with a high-quality education.

\section{Acknowledgment}

The authors would like to express gratitude for teachers, parents, and students of SLB of Kota Langsa Aceh Indonesia to provide support and assistance during this research.

\section{Bibliography}

Akmanoğlu, N., \& Ersan, D. T. (2020). A study of instructors' educational background who are instructing special education teachers in teaching practice course. Elementary Education Online, 19(2), 757-765. https://doi.org/10.17051/ilkonline.2020.694110

Alnahdi, G. H., Saloviita, T., \& Elhadi, A. (2019). Inclusive education in Saudi Arabia and Finland: pre-service teachers' attitudes. Support for Learning, 34(1), 71-85. https://doi.org/10.1111/1467-9604.12239

Andersa, Y., Sammons, P., Taggartc, B., Sylva, K., Melhuish, E., \& Siraj-Blatchford, I. (2011). The influence of child, family, home factors and pre-school education on the identification of special educational needs at age 10. British Educational Research Journal, 37(3), 421-441. https://doi.org/10.1080/01411921003725338

Arthur, C., Badertscher, E., Paul, G., Baette, M., Matt, M., Johannah, N., \& Kristen, R. (2017). Strategies to improve all students' mathematics learning and achievement. Waltham, MA: EDC.

Bagley, C., Woods, P. A., \& Woods, G. (2001). Implementation of School Choice Policy: Interpretation and response by parents of students with special educational needs. British Educational Research Journal, 27(3), 287-311. 
https://doi.org/10.1080/01411920120048313

Banda, D., \& Kubina Jr., R. (2009). Increasing academic compliance with mathematics tasks using the high-preference strategy with a student with autism. Preventing School Failure: Alternative Education for Children and Youth, 54(2), 81-85. https://doi.org/10.1080/10459880903217564

Budiyanto, B., Sheehy, K., Kaye, H., \& Rofiah, K. (2020). Indonesian educators' knowledge and beliefs about teaching children with autism. Athens Journal of Education, 7(1), 7798. https://doi.org/10.30958/aje.7-1-4

Burns, M. S. (2012). New views into the science of educating children with autism. Phi Delta Kappan, 94(4), 8-11. https://doi.org/10.1177/003172171209400403

Contreras, D., Brante, M., Espinoza, S., \& Zuñiga, I. (2020). The effect of the integration of students with special educational needs: Evidence from Chile. International Journal of Educational Development, 102163. https://doi.org/10.1016/j.ijedudev.2020.102163

Creswell, J. W. (2007). Educational Research: Planning, conducting, and evaluating quantitative and qualitative research (4th Edition). SAGE Publications, Inc.

Daiva, Alifanovienè, A. V. (2011). Development of students' competences in special education studies, applying the description of the teacher's professional competence and research on students' opinion. Teacher Education, 17(17), 87-104.

Dorcas, 0. (2011). Attitude of regular students and academic performance of students with special needs in integrated setting. The Journal of International Social Research, 4(16).

Eskelson, S. L. (2019). Examining secondary mathematics and special education preservice teachers' engagement in mathematics consultations. Proceedings of The 41st Annual of PME-NA, 1(1), 1330-1335. https://doi.org/10.1016/S0033-3182(95)71696-6

Faragher, R., Stratford, M., \& Clarke, B. (2017). Teaching children with down syndrome in inclusive primary mathematics classrooms. Australian Primary Mathematics Classroom, 22(4), 14-16.

Gevarter, C., Bryant, D. P., Bryant, B., Watkins, L., Zamora, C., \& Sammarco, N. (2016). Mathematics interventions for individuals with autism spectrum disorder: A systematic review. Review Journal of Autism and Developmental Disorders, 3(3), 224238. https://doi.org/10.1007/s40489-016-0078-9

Graham, L. J. (2015). A Little Learning is a Dangerous Thing: Factors Influencing the Increased Identification of Special Educational Needs from the Perspective of Education Policy-makers and School Practitioners. International Journal of Disability, Development and Education, 62(1), 116-132. https://doi.org/10.1080/1034912X.2014.955791

Hallahan, D., Kauffman, James M. \& Pullen, P. C. (2006). ExceptionalLearner An Introduction to Special Education. PEARSON.

Hansen, M. (2014). Helping children with autism learn: Treatment (Issue 3). Nova Southeastern University.

Holm, M. E., Björn, P. M., Laine, A., Korhonen, J., \& Hannula, M. S. (2020). Achievement emotions among adolescents receiving special education support in mathematics. Learning and Individual Differences, 79(July 2019), 101851. https://doi.org/10.1016/j.lindif.2020.101851

Hu, Y.-H., Xing, J., \& Liang-Ping, T. (2018). The effect of a problem-oriented teaching method on university mathematics Learning. EURASIA Journal of Mathematics, Science and Technology Education, 14(5), 1695-1703. 
Hunt, J. H., Welch-Ptak, J. J., \& Silva, J. M. (2016). Initial understandings of fraction concepts evidenced by students with mathematics learning disabilities and difficulties: A framework. Learning Disability Quarterly, 39(4), 213-225. https://doi.org/10.1177/0731948716653101

Ilona, R. (2019). Autism: a cross-cultural perspective on service provision and capacity building. Knowledge Exchange Seminar Series 2016-17, 316-323. https://doi.org/10.4324/9781315163437-21

Ismail, \& Muh, I. (2011). Pemberian rangkuman sebagai strategi pembelajaran. Formatif: $\begin{array}{llll}\text { Jurnal Ilmiah MIPA, } & 1(1), & \text { 48-57. }\end{array}$ https://doi.org/10.30998/formatif.v1i1.62

Istiarsyah, Hasan, D., \& Noor Aini, A. (2019). The influence of special education training on teachers' attitudes towards inclusive education: Case study in Aceh Province. Indonesia. International Journal of Academic Research in Progressive Education and Development, 8(4), 1016-1027. https://doi.org/10.6007/IJARPED/v8-i4/6901

Joubert, J., \& Slabbert, J. (2017). Facilitating transformative learning: supporting students experiencing unique challenges. Support for Learning, 32(2), 180-194. https://doi.org/10.1111/1467-9604.12161

Kim, D., Bae, S., Choi, S., \& Kim, H. (2019). Creative character education in mathematics for prospective teachers. Sustainability, 11(6), 16. https://doi.org/10.3390/su11061730

Kroesbergen, E. H., \& Johannes, E. H. V. L. (2003). Mathematics interventions for children with special educational needs. Remedial And Special Education, 24(2), 97-114.

Lanani, K. (2013). Belajar berkomunikasi dan komunikasi untuk belajar dalam pembelajaran matematika. Infinity Journal, $2(1), \quad 13$. https://doi.org/10.22460/infinity.v2i1.21

Lipsky, M., \& Kantor, J. (2019). Identification of challenges and strengths of children with special educational needs in their musical improvisations. Clinical Psychology and Special EduсаtionКлиническая и Специальная Психология, 8(1), 118-136. https://doi.org/10.17759/cpse.2019080108

Loughran, S. B. (2008). The importance of teacher/parent partnerships: Preparing preservice and in-service teachers. Journal of College Teaching \& Learning (TLC), 5(8), 35-38. https://doi.org/10.19030/tlc.v5i8.1239

Mensah, F. A., \& Badu-Shayar, J. (2016). Identification of special educational needs for early childhood inclusive education in Ghana. Journal of Education and Practice, 7(11), 1-8.

Moscardini, L. (2015). Primary special school teachers' knowledge and beliefs about supporting learning in numeracy. Journal of Research in Special Educational Needs, 15(1), 37-47. https://doi.org/10.1111/1471-3802.12042

Muttiah, N., Drager, K. D. R., McNaughton, D., \& Perera, N. (2018). Evaluating an AAC training for special education teachers in Sri Lanka,a low- and middle-income country. AAC: Augmentative and Alternative Communication, 34(4), 276-287. https://doi.org/10.1080/07434618.2018.1512651

Ngiamsunthorn, P. S. (2020). Promoting creative thinking for gifted students in undergraduate mathematics. JRAMathEdu (Journal of Research and Advances in Mathematics Education), 5(1), 13-25. https://doi.org/10.23917/jramathedu.v5i1.9675

Onaolapo, A., \& Onaolapo, 0. (2017). Global data on autism spectrum disorders prevalence: A review of facts, fallacies and limitations. Universal Journal of Clinical Medicine, 5(2), 
14-23. https://doi.org/10.13189/ujcm.2017.050202

Palinussa, A. L. (2013). Students' critical mathematical thinking skills and character: Experiments for junior high school students through realistic mathematics education culture-based. IndoMS.J.M.E, 4(1), 75-94.

Powell, S. R., Berry, K. A., \& Benz, S. A. (2020). Analyzing the word-problem performance and strategies of students experiencing mathematics di ffi culty. Journal of $\begin{array}{lll}\text { Mathematical Behavior, } & \text { 58(January), }\end{array}$ https://doi.org/10.1016/i.jmathb.2020.100759

Rexroat-Frazier, N., \& Chamberlin, S. (2019). Best practices in co-teaching mathematics with special needs students. Journal of Research in Special Educational Needs, 19(3), 173-183. https://doi.org/10.1111/1471-3802.12439

Riany, Y. E., Cuskelly, M., \& Meredith, P. (2016). Cultural beliefs about autism in Indonesia. International Journal of Disability, Development and Education, 63(6), 623-640. https://doi.org/10.1080/1034912X.2016.1142069

Rodd, M. (2006). Commentary: Mathematics, emotion and special needs. Educational Studies in Mathematics, 63(2), 227-234. https://doi.org/10.1007/s10649-005-9014$\underline{0}$

Sabaruddin. (2019). Penilaian Penerapan Pendidikan Karakter dalam Pengajaran dan Pembelajaran Matematika Sekolah Dasar. University Pendidikan Sultan Idris (UPSI), Malaysia.

Sabaruddin, D., Fenny, A., \& Rita, S. (2019). Penggunaan Media Kartu Angka Untuk Peningkatan Kemampuan Pengenalan Numerik Pada Anak Autis. Jurnal Bidang Pendidikan Dasar, 3(2), 15-24. https://doi.org/10.21067/jbpd.v3i2.3375

Santos, M. I., Breda, A., \& Almeida, A. M. (2017). Design approach of mathematics learning activities in a digital environment for children with autism spectrum disorders. Educational Technology Research and Development, 65(5), 1305-1323. https://doi.org/10.1007/s11423-017-9525-2

Saulius Sukys, A. S. (2015). Parental involvement in inclusive education of children with special educational needs. Social Behavior and Personality, 43(2), 327-338.

Sugiman, Suyitno, H., Junaedi, I., D. (2020). The Creation of Teaching Aids for Disabled Students as Mathematical-Thinking-Imaginative Product. International Journal of Instruction, 13(3), 777-788.

Suhuddinul Islam, M., \& Suparman. (2019). Design development of interactive mathematics learning media based on character education using macromedia flash. International Journal Of Scientific \& Technology Research, 8(12), 2855-2859.

Sukardjo, M. (2020). Effect of concept attainment models and self-directed learning (SDL) on mathematics learning outcomes. International Journal of Instruction E-ISSN:, 13(3).

Tolentino, R. M. (2016). Improving math skills of special education students. International Journal of Advanced Research in Education \& Technology (IJARET), 3(2), 73-77.

Tzanakaki, P., Brown, N., Farmer, K., Fraser-Smith, J., Mcclatchey, K., Mckeown, V., Sangster, A., Shaver, I., \& Templeton, J. (2014). An individualised curriculum to teach numeracy skills to children with autism: Programme description and pilot data. Support for Learning, 29(4), 319-338. https://doi.org/10.1111/1467-9604.12069

Xin, Y. P., \& Tzur, R. (2016). Cross-disciplinary thematic special series: Special education and mathematics education. Learning Disability Quarterly, 39(4), 196-198. https://doi.org/10.1177/0731948716669816 